\title{
PENGARUH PEMBERIAN ZAT MULTI GIZI MIKRO DAN PENDIDIKAN GIZI TERHADAP PENGETAHUAN GIZI, PEMENUHAN ZAT GIZI DAN STATUS BESI REMAJ A PUTRI
}

(The effect of Multi Micronutrients Supplementation and Nutrition Education on Nutrition Knowledge, Nutrients Adequacy Ratio and Iron Status of Young Adolescent Girls)

\author{
Cesilia Meti Dwiriani ${ }^{1} *$ Rimbawan ${ }^{1}$, Hardinsyah $^{1}$, Hadi Riyadi $^{1}$, dan Drajat Martianto ${ }^{1}$ \\ ${ }^{1}$ Departemen Gizi Masyarakat, Fakultas Ekologi Manusia, Institut Pertanian Bogor, Bogor 16680 \\ * Alamat korespondensi: Departemen Gizi Masyarakat, Fakultas Ekologi Manusia, Institut Pertanian \\ Bogor, Bogor 16680. Telp: 0251-8621258; Fax: 0251-8622276; email: cmetid@yahoo.com
}

\begin{abstract}
ABST RACT
This study was aimed to analyze the effect of multi-micronutrients (MMN) supplementation and nutrition education on nutrition knowledge, mean adequacy ratio (MAR) and iron status of young adolescent girls (YAG). The study was done in three purposively selected junior high schools (J HS) in rural Bogor by implementing a quasi experiment control trial for 112 YAG for 16 weeks: thirty five YAG in the first J HS as a MMN group (SG) were given three times of MMN tablets per week, forty two YAG in the second J HS were given MMN tablet plus nutrition education delivered by trained teacher fortnightly called SGP group and thirty five YAG in the third JHS as a control group. The result showed that the increment of nutrition knowledge score as well as MAR of SGP group were significantly higher than the other two groups. The decrement level of hemoglobin $(\mathrm{Hb})$ in SG and SGP groups was significantly lower than in control group, but in the subset data of anemic group, both intervention groups had significantly increased level of $\mathrm{Hb}$. This imply that nutrition education improved nutrition knowledge of YAG, but MMN tablet could not improve Hb level in general and only had effect on YAG suffering from anemia.
\end{abstract}

Key words: multi-micro nutrients, nutrition education, iron status, adolescent girls

\section{PENDAHULUAN}

Anemia merupakan masalah gizi utama yang dijumpai pada remaja wanita di dunia maupun di Indonesia. Depkes RI (2005) melaporkan prevalensi 26.5 persen pada remaja wanita 15-19 tahun, sementara Permaesih dan Herman (2005) melaporkan 30 persen pada remaja wanita 10-19 tahun. Penelitian terserak di beberapa wilayah Indonesia menunjukkan prevalensi yang bervariasi, yaitu 17.2-80.2 persen (Angeles-Agdeppa et al. 1997, Depkes RI 2003). Anemia disebabkan tidak hanya oleh kekurangan zat besi, tetapi zat gizi mikro lainnya seperti asam folat, vitamin A, vitamin C, riboflavin dan vitamin B12 juga berperan dalam terjadinya anemia, karena zat-zat gizi tersebut berperan dalam eritropoiesis (pembentukan sel darah merah) dan metabolisme besi (Beard 2000; Allen 2002).

Suplementasi zat besi dan folat dengan penambahan zat gizi mikro lainnya pada remaja telah dilakukan beberapa peneliti Ahmed, Khan, dan Jackson (2001); Soekarjo et al. (2004); J ayatissa dan Piyasena (1999); AngelesAgdeppa et al. (1997); Dillon (2005); Briawan (2008). Hasilnya menunjukkan penambahan zat besi dan folat dengan vitamin dan mineral lainnya diantaranya dapat memperbaiki status besi.

Upaya mengatasi masalah gizi disarankan dilakukan dengan pendekatan yang lebih berkelanjutan dan mempunyai nilai pengembalian ekonomi (economic return) yang relatif tinggi (World Bank 2006), yaitu melalui intervensi pendidikan gizi agar terjadi perubahan perilaku makan sehingga nantinya penurunan prevalensi anemia dapat lebih dicapai. Remaja dapat dikatakan merupakan target ideal pendidikan gizi, karena remaja umumnya bersifat lebih terbuka serta menunjukkan keingintahuan dan ketertarikan terhadap ide atau pengetahuan baru.

Peningkatan pengetahuan gizi remaja yang kemudian diharapkan dapat memperbaiki sikap serta perilaku makan remaja dapat dilakukan melalui sekolah dengan pertimbangan: 1) remaja menghabiskan sebagian besar waktunya di sekolah dan 2) sekolah memiliki guru Bimbingan dan Konseling (BK) yang berkewajiban memberi bantuan kepada siswa dalam upaya menemukan pribadi, mengenal lingkungan dan merencanakan masa 
depan atau bimbingan dalam hal pribadi, sosial, belajar dan karier.

Berdasarkan pertimbangan di atas perlu dikaj i dampak intervensi gizi melalui sekolah, yaitu dengan pendidikan gizi dan suplementasi berbagai zat gizi mikro. Pertanyaan yang akan dijawab dalam penelitian ini adalah apakah suplementasi gizi mikro dan pendidikan gizi dapat meningkatkan pengetahuan gizi dan pemenuhan zat gizi serta memperbaiki status besi remaja putri?

Penelitian ini bertujuan: 1) menganalisis pengetahuan gizi, tingkat pemenuhan zat gizi, dan status besi remaja putri, 2) menganalisis pengaruh intervensi suplementasi zat gizi mikro dan pendidikan gizi terhadap pengetahuan gizi, pemenuhan zat gizi dan status besi remaja putri. Hasil penelitian diharapkan dapat menjadi salah satu alternatif model program pencegahan anemi bagi remaja putri.

\section{METODE}

\section{Desain dan Lokasi}

Desain penelitian adalah quasy experiment control trial. Contoh dikelompokkan dalam tiga perlakuan, yaitu suplementasi multi gizi mikro (SG) dan SG plus pendidikan gizi (SGP) serta kelompok kontrol.

Penelitian dilakukan di tiga SMP di Kabupaten Bogor. Pemilihan sekolah dilakukan secara purposive dengan pertimbangan: 1) tersedia guru Bimbingan dan Konseling (BK) yang akan memberikan pendidikan gizi dan 2) murid-murid di ketiga sekolah tersebut memiliki keadaan sosial ekonomi budaya yang relatif sama. Dari penjajagan terhadap delapan sekolah, dipilih tiga sekolah sebagai lokasi pene- litian. Alokasi perlakuan pada sekolah dilakukan secara acak. Penelitian dilakukan September 2009-J uni 2010.

\section{Cara Pemilihan Sampel}

Contoh adalah remaja putri kelas I dan II SMP dengan kriteria inklusi: 1) sudah menarche, 2) menderita anemia marginal ( $\mathrm{Hb}$ $\leq 12.5 \mathrm{~g} / \mathrm{dL}$ hasil pemeriksaan menggunakan HemoCue AB, Angelholm, Sweden, 3) bersedia berpartisipasi selama 4 bulan dengan menandatangani informed consent yang juga ditandatangani oleh orang tua, 5) tidak sedang menderita infeksi yang disertai panas saat pengumpulan darah yang didasarkan hasil pemeriksaan dokter.

Dari ketiga sekolah terpilih terdapat 761 siswi kelas I dan II, dimana 381 siswi (50.1\%) sudah menarche. Pengukuran $\mathrm{Hb}$ dengan HemoCue $A B$ terhadap 359 siswi yang sudah menstruasi menunjukkan 139 siswi atau sejumlah 38.7 persen contoh terkategori anemia marginal. Gambar 1 menunjukkan prosedur pengambilan contoh.

\section{J enis dan Cara Pengumpulan Data}

Data karakteristik contoh (tanggal lahir, berat dan tinggi badan [BB dan TB], usia menarche, jumlah uang saku dan uang jajan per hari) dan karakateristik keluarga (pendidikan, pekerjaan dan pendapatan orang tua, serta besar keluarga) dikumpulkan menggunakan kuesioner yang diisi sendiri oleh contoh setelah diberi penjelasan peneliti. Data BB dikumpulkan menggunakan timbangan digital merk Boso (ketelitian $0.1 \mathrm{~kg}$ ), TB menggunakan microtoise (ketelitian $0.1 \mathrm{~cm}$ ). Pengukuran dilakukan dengan metode standar.

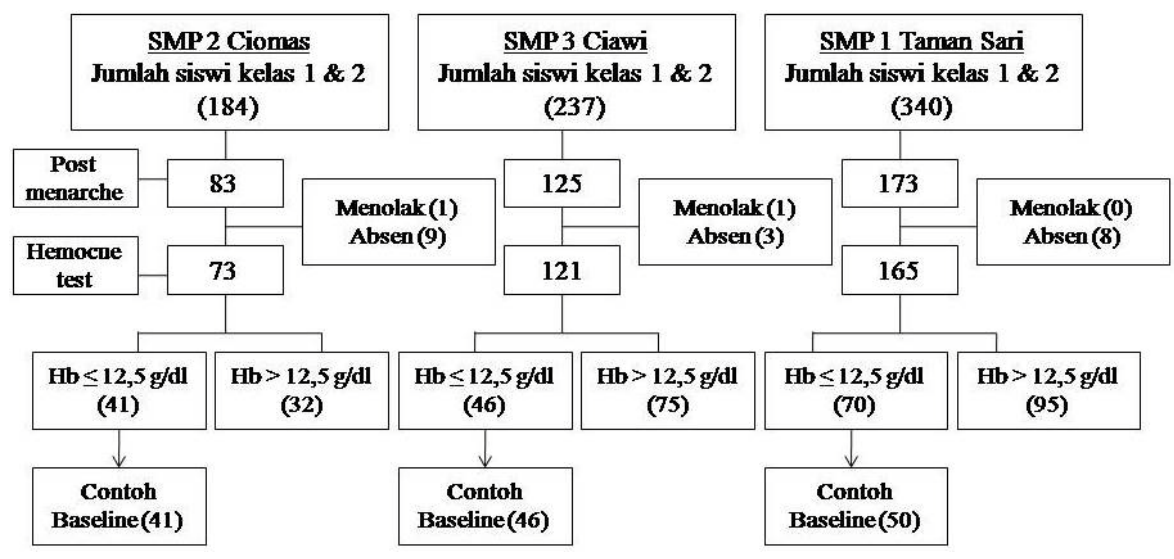

Gambar 1. Prosedur Pengambilan Contoh 
Data perkiraan konsumsi pangan dikumpulkan dengan metode recall 1 x 24 jam. Pengetahuan gizi diukur dengan 25 pertanyaan, yang dibagi dalam lima topik, yaitu: 1) gizi umum (5 pertanyaan), 2) gizi remaja (5 pertanyaan), 3) pangan sumber zat gizi (4 pertanyaan), 4) fungsi dan akibat kekurangan/ kelebihan zat gizi (5 pertanyaan) dan 5) anemia ( 6 pertanyaan). Data status besi diukur dengan hemoglobin $(\mathrm{Hb})$, hematokrit $(\mathrm{Ht})$ dan serum transferin receptor (STfR). Pengambilan sampel darah dilakukan oleh tenaga medis terlatih dan dianalisis dengan metode standar pada laboratorium yang sudah terakreditasi, yaitu di Labora-torium Biokimia, Pusat Penelitian Teknologi Terapan Kesehatan dan Epidemiologi Klinik Kemenkes RI.

\section{Pengolahan dan Analisis Data}

Data BB dan TB diolah untuk menghitung indeks massa tubuh (IMT). Pengelompokan status gizi dilakukan dengan software AnthroPlus (WHO 2007). Data perkiraan intake energi dan zat gizi (protein, vitamin A, C dan besi) diperperoleh dengan mengkonversi bahan pangan yang dikonsumsi menggunakan Daftar Komposisi Bahan Makanan (DKBM). Mean adequacy ratio (MAR) dihitung untuk mengetahui pemenuhan zat gizi, selisih nilai variabel respon sebelum dan setelah intervensi dilakukan uji ANOVA. Sebelum uji ANOVA, diuji normalitas data dengan uji Komolgov-Smirnov. Uji ANOVA dilanjutkan dengan uji LSD, jika ditemukan perbedaan pada $\mathrm{p} \ll 0.05$ antar kelompok perlakuan.

\section{HASIL DAN PEMBAHASAN}

\section{Karakteristik Contoh}

Umur contoh berkisar antara 12-16 tahun dan lebih dari 90 persen berusia 13-15 tahun (Tabel 1). Bila dibandingkan antar kelompok perlakuan, umur contoh kelompok SG signifikan lebih tua. Usia menarche, yaitu usia menstruasi pertama kali, berkisar 10-14 tahun. Status gizi contoh berkisar dari sangat kurus sampai obes, dengan nilai z berkisar -3.4 sampai +2.5. Pada masing-masing kelompok, lebih dari 85 persen contoh berstatus gizi normal.

Besarnya uang saku contoh per hari berkisar antara Rp 2 000-Rp 15 000. Rata-rata uang saku relatif sama antar kelompok SGP dan Kontrol, namun signifikan lebih rendah pada kelompok SG. Uang jajan contoh mempunyai kisaran yang sama dengan uang saku, besarnya relatif sama antar kelompok SGP dan SG, namun signifikan lebih tinggi pada kelompok Kontrol. Hal ini menunjukkan meskipun contoh SGP dan Kontrol memiliki uang saku relatif sama, contoh Kontrol membelanjakan uangnya lebih banyak untuk jajan.

Tabel 1. Sebaran Contoh berdasarkan Karakteristik Individu

\begin{tabular}{|c|c|c|c|c|}
\hline Karakteristik Individu & $\begin{array}{c}\text { Kontrol } \\
\text { n (\%) } \\
\end{array}$ & $\begin{array}{c}\text { SG } \\
\text { n (\%) }\end{array}$ & $\begin{array}{c}\text { SGP } \\
\mathrm{n}(\%)\end{array}$ & $\begin{array}{l}\text { Total } \\
\text { n (\%) }\end{array}$ \\
\hline Umur (tahun) & $13.80 \pm 0.76^{\mathrm{a}}$ & $14.31 \pm 1.02^{b}$ & $13.88 \pm 0.71^{\mathrm{a}}$ & $13.99 \pm 0.85$ \\
\hline $\begin{array}{c}<13 \\
13-15 \\
>15\end{array}$ & $\begin{array}{c}1(2.9) \\
34(97.1) \\
0(0.0)\end{array}$ & $\begin{aligned} & 0(0.0) \\
& 31(88.6) \\
& 4(11.4) \\
&\end{aligned}$ & $\begin{aligned} & 1(2.4) \\
& 41(97.6) \\
& 0(0.0) \\
&\end{aligned}$ & $\begin{array}{c}2(1.8) \\
106(94.6) \\
4(3.6) \\
\end{array}$ \\
\hline Usia Menarche (tahun) & $11.80 \pm 0.83^{\mathrm{a}}$ & $12.14 \pm 0.94^{\mathrm{a}}$ & $12.13 \pm 0.67^{\mathrm{a}}$ & $12.03 \pm 0.82$ \\
\hline $\begin{array}{l}<12 \\
12 \\
>13\end{array}$ & $\begin{array}{l}13(37.2) \\
16(45.7) \\
6(17.2)\end{array}$ & $\begin{array}{c}8(22.9) \\
16(45.7) \\
11(31.5)\end{array}$ & $\begin{array}{c}7(16.7) \\
23(54.8) \\
12(28.6)\end{array}$ & $\begin{array}{l}28(25.0) \\
55(49.1) \\
29(25.9)\end{array}$ \\
\hline Status Gizi (nilai z IMT/ U) & $-0.03 \pm 1.07^{a}$ & $-0.24 \pm 1.15^{\mathrm{a}}$ & $-0.37 \pm 1.03^{a}$ & $-0.22 \pm 1.08$ \\
\hline $\begin{array}{l}\text { Kurus/ s. kurus }(<-2.0) \\
\text { Normal }(-2.0 \mathrm{~s} / \mathrm{d}+0.9) \\
\text { Overweight/ obese }(\geq+1.0)\end{array}$ & $\begin{aligned} 0 & (0.0) \\
30 & (85.7) \\
5 & (14.3)\end{aligned}$ & $\begin{aligned} 2 & (5.7) \\
31 & (88.6) \\
2 & (5.7)\end{aligned}$ & $\begin{aligned} 2 & (4.8) \\
36 & (85.7) \\
4 & (9.5)\end{aligned}$ & $\begin{array}{c}4(3.6) \\
97(86.6) \\
11(9.8)\end{array}$ \\
\hline Uang Saku (Rp/ hari) & $6.604 \pm 2.452^{\mathrm{a}}$ & $5.431 \pm 2.353^{b}$ & $6.046 \pm 2.304^{\mathrm{a}}$ & $6.028 \pm 2.447$ \\
\hline $\begin{array}{l}<\operatorname{Rp} 3000 \\
>\operatorname{Rp} 3000\end{array}$ & $\begin{array}{c}2(5.7) \\
33(94.3)\end{array}$ & $\begin{array}{c}7(20.0) \\
28(80.0)\end{array}$ & $\begin{array}{c}5(11.9) \\
37(88.1)\end{array}$ & $\begin{array}{l}14(12.5) \\
98(87.5)\end{array}$ \\
\hline Uang jajan (Rp/ hari) & $5.600 \pm 2.075^{a}$ & $4.029 \pm 1.823^{b}$ & $4.393 \pm 2.320^{b}$ & $4.656 \pm 2.181$ \\
\hline $\begin{array}{l}\leq \operatorname{Rp} 3000 \\
>\operatorname{Rp} 3000\end{array}$ & $\begin{array}{c}4(11.4) \\
31(88.6)\end{array}$ & $\begin{array}{l}18(51.4) \\
17(48.6)\end{array}$ & $\begin{array}{l}19(45.2) \\
23(54.8)\end{array}$ & $\begin{array}{l}41(36.6) \\
71(63.4)\end{array}$ \\
\hline
\end{tabular}

a, Nilai rata-rata dan standar deviasi variabel yang diamati. Pada baris yang sama, huruf yang sama menunjukkan tidak terdapat perbedaan nyata $(p>0.05)$ 
Karakteristik keluarga contoh menunjukkan besar keluarga contoh berkisar 2-9 orang dan hampir separuh (49.1\%) contoh memiliki besar keluarga 5-6 orang atau terkategori sebagai keluarga sedang, yaitu memiliki anak 3-4 orang. Besar keluarga contoh kelompok SG signifikan lebih banyak dibandingkan kelompok SGP dan Kontrol.

Pendidikan formal orangtua contoh berkisar antara Iulusan SD sampai Iulusan akademi. Hampir separuh ayah (46\%) dan ibu (44\%) contoh berpendidikan setingkat SMP dan SMA, namun lebih dari separuh ibu contoh (54\%) berpendidikan SD. Jika pendidikan formal orangtua dikonversi ke lama menempuh pendidikan formal (tahun) tampak bahwa pendidikan formal orangtua contoh pada tiga kelompok perlakuan relatif sama.

Hasil uj i statistik menunjukkan terdapat hubungan signifikan yang negatif antara status gizi dengan usia ( $p=0.000 ; r=0.541)$ dan status gizi dengan usia menarche $(p=0.000 ; r=0.343)$. Artinya semakin bertambah usia, status gizi contoh semakin menjauhi normal dan semakin baik status gizi, usia menarche contoh semakin muda. Hal ini sejalan dengan laporan WHO (1995), Allen dan Gillespie (2001) dan WHO (2005). Contoh dengan status gizi yang lebih baik cenderung memiliki status kesehatan yang lebih baik pula dan hal ini akan mempengaruhi kematangan (maturity) sistem hormon, sehingga contoh mengalami menstruasi lebih dini (WHO 1995).

\section{Pengetahuan Gizi}

Rata-rata skor pengetahuan gizi sebelum intervensi relatif sama antar kelompok perla- kuan (Tabel 2), kecuali pada topik gizi secara umum skor kelompok Kontrol signifikan lebih tinggi. Secara umum tingkat pengetahuan gizi seluruh contoh terkategori kurang, karena rata-rata skor pengetahuan gizi menunjukkan penguasaan materi masih kurang dari 60 persen.

\section{Asupan Energi dan Zat Gizi}

Rata-rata asupan energi dan zat gizi (protein, vitamin $A, C$ dan zat besi) contoh relatif sama, kecuali konsumsi energi kelompok SG yang signifikan lebih rendah (Tabel 3). Terdapat lebih dari separuh contoh yang asupannya <70 persen angka kecukupan gizi (AKG), sedangkan contoh dengan intake $>110$ persen AKG ditemui kurang dari 10 persen contoh. Intake contoh tampak lebih buruk dibandingkan hasil Riskesdas 2010 (Depkes RI 2010) dan bila dihitung MAR contoh, nilainya berkisar antara 15-100 persen dan antar kelompok perlakuan tidak berbeda $(p>0.05)$. Asupan contoh yang relatif rendah ini diduga sebagian disebabkan kebiasaan sarapan dan jajan contoh yang relatif kurang baik, dimana terdapat sekitar 10 persen contoh tidak pernah sarapan pagi dan 10 persen lainnya hanya sarapan 1-2 kali per minggu serta frekuensi makan lengkap tiga kali sehari hanya dilakukan oleh kurang dari 30 persen contoh. Namun hampir 90 persen contoh jajan setiap hari di sekolah dan sekitar separuh contoh juga jajan setiap hari di rumah. Kebiasaan jajan contoh baik di sekolah dan di rumah menunjukkan perlunya bekal pengetahuan gizi yang cukup agar contoh dapat membeli makanan jajanan yang bergizi dengan jatah uang jajan yang dimiliki, yang diperlukan untuk pertumbuhan di masa remaja.

Tabel 2. Rata-rata Skor Pengetahuan Gizi Sebelum Intervensi

\begin{tabular}{|c|c|c|c|c|}
\hline Topik & Kontrol & SG & SGP & Total \\
\hline 1. Gizi umum & $58.3 \pm 14.0^{\mathrm{a}}$ & $52.6 \pm 12.0^{b}$ & $51.4 \pm 10.0^{6}$ & $53.9 \pm 12.3$ \\
\hline 2. Gizi remaja & $56.7 \pm 16.8^{a}$ & $54.3 \pm 15.3^{\mathrm{a}}$ & $52.4 \pm 14.5^{\mathrm{a}}$ & $54.3 \pm 14.6$ \\
\hline 3. Sumber gizi & $25.7 \pm 15.0^{\mathrm{a}}$ & $21.1 \pm 15.3^{\mathrm{a}}$ & $24.8 \pm 13.1^{\mathrm{a}}$ & $23.9 \pm 14.4$ \\
\hline 4. Fungsi, akibat kurang/ lebih gizi & $37.7 \pm 21.0^{\mathrm{a}}$ & $33.7 \pm 21.0^{\mathrm{a}}$ & $34.8 \pm 25.0^{a}$ & $35.4 \pm 22.5$ \\
\hline 5. Anemia & $37.8 \pm 17.9^{a}$ & $34.3 \pm 18.0^{\mathrm{a}}$ & $40.5 \pm 15.7^{\mathrm{a}}$ & $37.7 \pm 17.2$ \\
\hline Total skor & $43.2 \pm 8.6^{\mathrm{a}}$ & $39.2 \pm 7.9^{b}$ & $40.8 \pm 7.8^{\mathrm{a}, \mathrm{b}}$ & $41.0 \pm 8.2$ \\
\hline
\end{tabular}

Tabel 3. Rata-rata Perkiraan Intake Energi dan Zat Gizi Contoh Sebelum Intervensi

\begin{tabular}{lcccc}
\hline \multicolumn{1}{c}{ Intake/hr } & Kontrol & SG & SGP & Total \\
\hline Energi (kkal) & $1557 \pm 419^{\mathrm{a}}$ & $1351 \pm 431^{\mathrm{b}}$ & $1552 \pm 317^{\mathrm{a}}$ & $1491 \pm 396$ \\
Protein (g) & $38.5 \pm 12.7^{\mathrm{a}}$ & $35.7 \pm 11.5^{\mathrm{a}}$ & $35.7 \pm 10.3^{\mathrm{a}}$ & $36.6 \pm 11.4$ \\
Vit. A (RE) & $484.8 \pm 311^{\mathrm{a}}$ & $410.3 \pm 431^{\mathrm{a}}$ & $359.1 \pm 279^{\mathrm{a}}$ & $414.4 \pm 343$ \\
Vit. C (mg) & $33.8 \pm 68.2^{\mathrm{a}}$ & $20.2 \pm 23.6^{\mathrm{a}}$ & $23.3 \pm 312^{\mathrm{a}}$ & $25.6 \pm 44.6$ \\
Zat besi (mg) & $12.9 \pm 13.5^{\mathrm{a}}$ & $15.3 \pm 15.4^{\mathrm{a}}$ & $11.7 \pm 5.9^{\mathrm{a}}$ & $13.2 \pm 12.0$ \\
MAR & $58.0 \pm 22.4^{\mathrm{a}}$ & $55.2 \pm 26.9^{\mathrm{a}}$ & $51.7 \pm 22.3^{\mathrm{a}}$ & $54.8 \pm 23.8$ \\
\hline a,b Pada baris yang sama, huruf yang sama menunjukkan tidak terdapat perbedaan nyata (p>0.05)
\end{tabular}




\section{Status Besi}

Konsentrasi Hb contoh berkisar 9.2-15.2 $\mathrm{g} / \mathrm{dl}$ dan jika dikelompokkan berdasarkan kriteria ACC/SCN (1991) terdapat 14.3 persen contoh yang anemi ringan dan 0.9 persen contoh yang anemia sedang dan rata-rata nilai $\mathrm{Hb}$ ketiga kelompok perlakuan adalah sama. Kadar Ht contoh berkisar 26-43 persen dan menggunakan standar $\geq 36$ persen sebagai batas normal (WHO/ UNICEF/UNU, 2001) terdapat 21.4 persen contoh anemia. Gibson (2005) menyatakan bahwa penggunaan data $\mathrm{Ht}$ saja tidak cukup untuk secara konklusif mendeteksi defisiensi besi, karena Ht akan menurun setelah pembentukan $\mathrm{Hb}$ mulai terganggu, sehingga pada defisiensi besi tingkat sedang dapat saja terjadi nilai $\mathrm{Hb}$ relatif rendah namun nilai $\mathrm{Ht}$ masih normal. Nilai STfR contoh berkisar 0.7-4. $6 \mathrm{ug} / \mathrm{ml}$ dan terda-pat 9.8 persen contoh dengan nilai STfR tinggi yang mengindikasikan telah terjadi defisiensi besi eritropoiesis/ defisiensi besi pada jaringan. Contoh pada kelompok Kontrol paling banyak mengalami defisiensi besi pada jaringan (17.1\%) dibandingkan dua kelompok lainnya (11.4\% dan 2.4\%). Rata-rata STfR signifikan lebih tinggi pada kelompok Kontrol yang menunjukkan gambaran lebih mengarah kepada defisiensi besi eritropoiesis.

Bila dihubungkan dengan karakteristik individu dan keluarga, nilai $\mathrm{Hb}$ dan $\mathrm{Ht}$ secara signifikan berhubungan negatif dengan umur (berturut-turut $p=0.022 r=0.217 ; p=0.007 r=$ 0.253 ). Artinya seiring dengan meningkatnya usia contoh, nilai $\mathrm{Hb}$ dan $\mathrm{Ht}$ contoh akan semakin rendah. Sebaliknya nilai STfR signifikan berhubungan positif dengan umur, dimana semakin meningkat usia contoh, nilai STfR contoh cenderung semakin tinggi $(p=0.036$ $r=0.198$ ), yang artinya semakin mengarah pada kondisi defisiensi. Hal ini diduga berhubungan dengan peningkatan kebutuhan zat besi selama usia remaja. WKNPG (2004) menetapan kecukupan besi $14 \mathrm{mg} / \mathrm{hr}$ untuk usia 10-12 tahun dan meningkat menjadi $26 \mathrm{mg} / \mathrm{hr}$ untuk usia 13-49 tahun, sedangkan FAO/ WHO (2001) menetapkan angka kebutuhan yang terus meningkat pada remaja usia 11-17 tahun kemudian menurun setelah 18 tahun. Peningkatan kebutuhan zat besi jika tidak diimbangi dengan asupan yang cukup akan menyebabkan nilai indikator status besi diatas menjauhi nilai normal.

\section{Kepatuhan Konsumsi Tablet MGM}

Tingkat kepatuhan contoh mengonsumsi tablet berkisar 70-100 persen (34-48 tablet) dan secara umum kelompok kontrol menunjukkan kepatuhan yang lebih tinggi dibandingkan dua kelompok lainnya. Hal ini diduga disebabkan adanya keluhan setelah mengkonsumsi tablet MGM, yaitu sakit perut pada sekitar dua per tiga contoh SG dan SGP serta keluhan mual pada sepertiga contoh SG dan SGP. Sakit perut dan mual dilaporkan merupakan gejala yang umum dirasakan bila mengkonsumsi tablet besi (UNICEF/ WHO/FAO 2001). Tablet besi disarankan dikonsumsi setelah makan, sehingga jika ada contoh yang belum sarapan (untuk yang masuk pagi) atau makan siang (untuk yang masuk siang) peneliti menyediakan makanan kecil (buras) untuk dikonsumsi contoh sebelum minum tablet MGM. Tindakan yang umumnya dilakukan contoh saat merasa sakit adalah menahan sakit dan meskipun contoh telah makan pagi di rumah atau makan makanan kecil yang disediakan peneliti, keluhan di atas masih dirasakan oleh sekitar separuh contoh.

\section{Pengaruh Intervensi terhadap Pengetahuan Gizi, Pemenuhan Zat Gizi dan Perbaikan Status Besi.}

Intervensi pendidikan gizi meningkatkan 28.6 skor pengetahuan gizi dan 8.7 nilai MAR kelompok SGP, signifikan lebih tinggi dibandingkan kelompok SG dan Kontrol (Tabel 4). Nilai $\mathrm{Hb}$ dan $\mathrm{Ht}$ contoh sebelum intervensi menunjukkan hubungan negatif dengan umur, artinya nilai $\mathrm{Hb}$ dan $\mathrm{Ht}$ contoh cenderung menurun dengan semakin meningkatkanya umur. Suplementasi MGM tiga kali seminggu selama empat bulan secara signifikan memberikan penurunan nilai $\mathrm{Hb}$ pada kelompok SG dan SGP yang lebih rendah dibandingkan pada kelompok Kontrol. Tampak bahwa selisih nilai Hb setelah dan sebelum intervensi pada kelompok Kontrol lebih besar dibandingkan kelompok SG dan SGP. Pengaruh signifikan tablet MGM terhadap kadar $\mathrm{Hb}$ juga terlihat pada jumlah contoh yang anemia setelah intervensi, dimana contoh kelompok Kontrol yang anemi (25\%) lebih banyak dibandingkan contoh anemi kelompok SG (11.4\%) dan SGP (9.5\%). Sebelum intervensi prevalensi anemia pada masingmasing kelompok perlakuan relatif sama, yaitu 17.1 persen pada pada Kontrol, 11.5 persen pada SG dan 16.7 persen pada SGP.

Pengaruh suplementasi tablet MGM tiga kali seminggu pada nilai Ht tidak signifikan meskipun nilai $\mathrm{Ht}$ setelah intervensi signifikan berbeda antara Kontrol dan SGP. Seperti diungkapkan terdahulu nilai $\mathrm{Ht}$ sebelum intervensi berhubungan signifikan negatif dengan umur, sehingga nilainya akan semakin menurun dengan semakin meningkatnya usia. Rata-rata 
nilai Ht setelah intervensi pada semua kelompok perlakuan menurun dan penurunan terbesar justru terdapat pada kelompok SGP kemudian diikuti kelompok SG dan kontrol.

Nilai STfR contoh sebelum intervensi ditemukan signifikan lebih tinggi pada kelompok kontrol dan berhubungan positif dengan usia contoh, artinya semakin tua usia, nilai STfR semakin tinggi atau semakin mengarah ke defisiensi besi. Tabel 4 menunjukkan nilai STfR setelah intervensi pada ketiga kelompok mempunyai kecenderungan yang sama, yaitu menurun, yang berarti mengarah pada nilai normal. Rata-rata penurunan nilai STfR bahkan tampak lebih besar pada kelompok Kontrol dibandingkan kelompok SG dan SGP.

Penelitian ini tidak dapat membuktikan suplementasi tablet MGM tiga kali seminggu pada remaja putri dapat meningkatkan hemoglobin diduga terutama disebabkan sebagian besar (84\%) contoh tidak anemi. Pada subset data contoh yang anemi (Tabel 5), menunjukkan intervensi signifikan menurunkan ratarata prevalensi anemia 73.2 persen, mening- katkan $\mathrm{Hb} 1.44 \mathrm{~g} / \mathrm{dl}$, Ht 2.6\% dan menurunkan STfR 1.4 mg/ dl pada kelompok SG dan SGP.

\section{KESIMPULAN}

Pengetahuan gizi hampir seluruh contoh terkategori kurang demikian pula intake energi dan zat gizi pada lebih dari separuh contoh masih kurang dari 70 persen AKG. Terdapat 15.2 persen contoh anemi dan tersebar merata pada masing-masing kelompok.

Intervensi pendidikan gizi signifikan meningkatkan 28.6 skor pengetahuan gizi dan 8.7 nilai pemenuhan kebutuhan zat gizi kelompok SGP lebih besar dibandingkan SG dan Kontrol. Suplementasi tablet MGM tidak dapat meningkatkan $\mathrm{Hb}$ contoh, namun signifikan lebih rendah menurunkan nilai $\mathrm{Hb}$ pada kelompok SG dan SGP dibandingkan Kontrol. Pada contoh anemi, suplementasi tablet MGM terbukti menurunkan prevalensi anemi dan meningkatkan kadar $\mathrm{Hb}$ dan $\mathrm{Ht}$.

Tabel 4. Skor Pengetahuan Gizi, Nilai MAR dan Status Besi Sebelum dan Setelah Intervensi

\begin{tabular}{|c|c|c|c|c|c|}
\hline Indikator & Waktu & Kontrol & SG & SGP & Total \\
\hline & Sebelum & $43.2 \pm 8.6^{\mathrm{a}}$ & $39.2 \pm 7.9^{b}$ & $40.8 \pm 7.8^{a, b}$ & $41.0 \pm 8.2$ \\
\hline \multirow[t]{2}{*}{ Skor Pengetahuan Gizi } & Setelah & $55.7 \pm 9.9^{\mathrm{a}}$ & $58.5 \pm 12.3^{a}$ & $69.3 \pm 15.2^{b}$ & $61.7 \pm 14.1$ \\
\hline & Selisih & $12.4 \pm 11.1^{\mathrm{a}}$ & $19.3 \pm 11.5^{b}$ & $28.6 \pm 13.7^{c}$ & $20.7 \pm 13.9$ \\
\hline \multirow{3}{*}{ MAR } & Sebelum & $58.0 \pm 22.4^{\mathrm{a}}$ & $55.2 \pm 26.9^{\mathrm{a}}$ & $51.7 \pm 22.3^{\mathrm{a}}$ & $54.8 \pm 23.6$ \\
\hline & Sesudah & $49.6 \pm 25.2^{\mathrm{a}}$ & $50.7 \pm 25.5^{a}$ & $60.4 \pm 25,4^{a}$ & $54.0 \pm 25.6$ \\
\hline & Selisih & $-8.5 \pm 29.7^{a}$ & $-4.5 \pm 34.6^{a}$ & $8.7 \pm 37.4^{\mathrm{b}}$ & $-0.8 \pm 34.8$ \\
\hline \multirow{3}{*}{$\mathrm{Hb}(\mathrm{g} / \mathrm{dL})$} & Sebelum & $13.38 \pm 1.34^{\mathrm{a}}$ & $13.29 \pm 1.34^{\mathrm{a}}$ & $13.03 \pm 0.93^{a}$ & $13.22 \pm 1.10$ \\
\hline & Setelah & $12.43 \pm 1.48^{\mathrm{a}}$ & $12.95 \pm 0.92^{\mathrm{a}}$ & $12.89 \pm 0.95^{a}$ & $12.76 \pm 1.15$ \\
\hline & Selisih & $-0.95 \pm 1.08^{b}$ & $-0.35 \pm 1.13^{a}$ & $-0.14 \pm 1.10^{a}$ & $-0.46 \pm 1.15$ \\
\hline \multirow{3}{*}{ Ht (\%) } & Sebelum & $38.03 \pm 2.75^{\mathrm{a}}$ & $37.31 \pm 3.75^{\mathrm{a}}$ & $37.00 \pm 2.23^{a}$ & $37.41 \pm 2.94$ \\
\hline & Setelah & $36.85 \pm 4.56^{\mathrm{a}, \mathrm{c}}$ & $36.07 \pm 2.36^{b, c}$ & $34.91 \pm 2.32^{b}$ & $35.88 \pm 3.27$ \\
\hline & Selisih & $-1.18 \pm 3.57^{\mathrm{a}}$ & $-1.24 \pm 3.05^{a}$ & $-2.09 \pm 2.52^{\mathrm{a}}$ & $-1.54 \pm 3.05$ \\
\hline \multirow{3}{*}{ STfR (ug/ mL) } & Sebelum & $2.06 \pm 0.87^{b}$ & $1.57 \pm 0.76^{\mathrm{a}}$ & $1.31 \pm 0.58^{\mathrm{a}}$ & $1.63 \pm 0.79$ \\
\hline & Setelah & $1.03 \pm 0.45^{\mathrm{a}}$ & $1.03 \pm 0.23^{a}$ & $0.97 \pm 0.25^{\mathrm{a}}$ & $1.01 \pm 0.31$ \\
\hline & Selisih & $-1.03 \pm 0.52^{a}$ & $-0.54 \pm 0.71^{\mathrm{D}}$ & $-0.34 \pm 0.45^{b}$ & $0.62 \pm 0.63$ \\
\hline
\end{tabular}

$a, b, c$ Pada baris yang sama, huruf yang sama menunj ukkan tidak terdapat perbedaan nyata $(p>0.05)$

Tabel 5. Nilai Hb, Ht dan STfR Contoh Anemi Sebelum dan Setelah Intervensi

\begin{tabular}{clcccc}
\hline \multicolumn{1}{c}{ Indikator } & Waktu & Kontrol & SG & SGP & Total \\
\hline Anemia (\%) & Sebelum & $6(100)$ & $4(100)$ & $7(100)$ & $17(100)$ \\
& Setelah & $5(83.3)$ & $1(25.0)$ & $2(28.6)$ & $8(47.1)$ \\
\hline Rata-rata Hb (g/ dl) & Sebelum & $11.7 \pm 0.2^{\mathrm{a}}$ & $10.6 \pm 1.0^{\mathrm{b}}$ & $11.6 \pm 0.2^{\mathrm{a}}$ & $11.4 \pm 0.7$ \\
& Setelah & $10.2 \pm 1.0^{\mathrm{a}}$ & $12.2 \pm 0.2^{\mathrm{b}}$ & $12.9 \pm 1.6^{\mathrm{b}}$ & $11.8 \pm 1.7$ \\
& Selisih & $-1.5 \pm 1.0^{\mathrm{a}}$ & $1.6 \pm 1.1^{\mathrm{b}}$ & $1.3 \pm 1.5^{\mathrm{b}}$ & $0.4 \pm 1.8$ \\
\hline Rata-rata Ht (\%) & Sebelum & $33.3 \pm 1.0^{\mathrm{a}}$ & $29.5 \pm 2.9^{\mathrm{b}}$ & $34.3 \pm 2.1^{\mathrm{a}}$ & $32.8 \pm 2.7$ \\
& Setelah & $30.3 \pm 2.9^{\mathrm{a}}$ & $33.9 \pm 0.7^{\mathrm{a}, \mathrm{b}}$ & $35.0 \pm 4.1^{\mathrm{b}}$ & $33.1 \pm 3.7$ \\
& Selisih & $-3.0 \pm 3.2^{\mathrm{a}}$ & $4.4 \pm 3.3^{\mathrm{a}, \mathrm{b}}$ & $0.7 \pm 3.9^{\mathrm{a}}$ & $0.2 \pm 4.4$ \\
\hline Rata-rata STfR (mg/ dl) & Sebelum & $3.0 \pm 0.8^{\mathrm{a}}$ & $3.4 \pm 0.3^{\mathrm{a}}$ & $1.7 \pm 0.7^{\mathrm{b}}$ & $2.6 \pm 1.0$ \\
& Setelah & $1.6 \pm 0.4^{\mathrm{a}}$ & $1.2 \pm 0.5^{\mathrm{a}, \mathrm{b}}$ & $1.0 \pm 0.2^{\mathrm{b}}$ & $1.3 \pm 0.4$ \\
& Selisih & $-1.4 \pm 0.6^{\mathrm{a}}$ & $-2.2 \pm 0.7^{\mathrm{a}, \mathrm{b}}$ & $-0.7 \pm 0.7^{\mathrm{a}}$ & $-1.3 \pm 0.9$ \\
\hline
\end{tabular}

${ }^{a, b}$ Pada baris yang sama, huruf yang sama menunj ukkan tidak terdapat perbedaan nyata $(p>0.05)$ 


\section{DAFTAR PUSTAKA}

Ahmed F, Khan MR, \& J ackson AA. 2001. Concomitant supplemental vitamin $A$ enhances the response to weekly supplemental iron folic acid in anemia teenagers in urban Bangladesh. Am J Clin Nutr, 74, 108-115.

Allen LH. 2002. Iron supplementation: scientific issues concerning efficacy and implications for research and programs. J Nutr 132:813S-819S

Angeles-Agdeppa I, Scultink W, Sastroamidjojo S, Gross R, \& Karyadi D. 1997. Weekly micornutrient supplementation to build iron stores in female Indonesian adolescents. Am J Clin Nutr, 66, 177 183.

Beard JL. 2000. Iron requirements in adolescent females. J Nutr 130:440S$442 S$.

Briawan D. 2008. Efikasi Suplementasi BesiMultivitamin terhadap Perbaikan Status Besi Remaja Wanita. Disertasi. SPS, IPB, Bogor.

Depkes RI. 2003. Program pencegahan anemia gizi besi pada wanita usia subur (WUS). Direktorat Gizi Masyarakat, Dirjen Kesehatan Masyarakat, Depkes RI, J akarta.

2005. Gizi dalam Angka. Direktorat Gizi Masyarakat, Dirjen Kesehatan Masyarakat, Depkes RI, Jakarta.

2010. Riset Kesehatan Dasar (RISKESDAS) 2010. Depkes RI: J akarta.

Dillon DHS. 2005. Nutritional health of Indonesian adolescent girls: the role of riboflavin and vitamin $A$ on iron status. Disertation. Wageningen University, Netherland.

FAO/WHO. 2001. Human Vitamin and Mineral Requirement. Report of joint $\mathrm{FAO} / \mathrm{WHO}$ expert consultation Bangkok, Thailand. FAO, Rome.

Fishman SM, Christian P, West KP. 2003. The role of vitamin in the prevention and control of anemia. Publ. Health Nutr. $3(2): 125-150$
Gibson RS. 2005. Principles of Nutritional Assessment. Second Edition. Oxford University Press, London.

Gillespie S, Kevany J, Manson J.1991. Contrrolling Iron Deficiency. A Report Based on an ACC-SCN Workshop. England: The Lavenham Press

Jayatissa R \& Piyasena C. 1999. Adolescent schoolgirls: daily or weekly iron supplementation. Food Nutr Bull, 20(4), 429-434.

Permaesih D \& Herman S. 2005. Factors affecting anemia on adolescentt. Health Research Bulletin, 33(4), 162171.

Prayitno. 1997. Pelayanan bimbingan dan konseling. Jakarta: PT Ikrar Mandiriabadi.

Soekarjo DD et al. 2004. Effectiveness of weekly vitamin A (10000 IU) and iron (60 mg) supplementation for adolescent boys and girls through schools in rural and urban East Java, Indonesia. Eur J Clin Nutr, 58, 927-937.

WHO. 1995. Physical status: the use and interpretation of anthropometry. WHO Technical Report Series 854. Report of a WHO Expert Committee. WHO, Geneva.

/ UNICEF/ UNU. 2001. Iron Deficiency Anemia, Assessment, Prevention and Control. A guide for programme manager. WHO, Geneva.

2005. Nutrition in adolescent: issues and challenges for the health sector: issues in adolescent health and development. WHO discussion papers on adolescent. Geneva: WHO.

World Health Organization/Centre for Disease Control and Prevention Technical Consultation on the Assessment of Iron Status at the Population Level, Geneva, Switzerland, 6-8 April 2004. WHO \& CDC, Geneva.

World Bank. 2006. Repositioning Nutrition as Central to Development. A Strategy for Large - Scale Action. Washington. 